May 2012

\title{
Value of the Research Methods Course: Voices from LIS Practitioners
}

Lili Luo

San Jose State University, lili.luo@sjsu.edu

Follow this and additional works at: https://scholarworks.sjsu.edu/ischoolsrj

Part of the Library and Information Science Commons

\section{Recommended Citation}

Luo, L. (2012). Value of the Research Methods Course: Voices from LIS Practitioners. School of Information Student Research Journal, 2(1). https://doi.org/10.31979/2575-2499.020102 Retrieved from https://scholarworks.sjsu.edu/ischoolsrj/vol2/iss1/2

This article is brought to you by the open access Journals at SJSU ScholarWorks. It has been accepted for inclusion in School of Information Student Research Journal by an authorized administrator of SJSU ScholarWorks. For more information, please contact scholarworks@sjsu.edu. 


\section{Value of the Research Methods Course: Voices from LIS Practitioners}

\section{Keywords}

research methodology, scholarship, curriculum 


\section{Value of the Research Methods Course: Voices from LIS Practitioners}

Library and Information Science (LIS) is a rapidly evolving field where practitioner research has become ever more important as it seeks "in a most rigorous manner, to understand and create efficient working practice" (Jarvis, 1999, p. xi). Research serves to create new knowledge and therefore contribute to the growth of LIS as a profession (Powell, Baker, \& Mika, 2002). A rising number of practitioner-researchers undertake their own research to meet "the need for more information for use in decision making at the managerial level, the need to keep abreast of new knowledge and procedures in this information society, and the need for continuing education and upgraded qualifications" (Jarvis, 1999, p. 7).

Hernon (2001) defined research as an inquiry process that has specific components, including reflective inquiry (problem statement, literature review and theoretical framework, logical structure, objectives, and research questions and hypotheses), procedures (research design and methods of data collection), data gathering/processing/analysis, issues of reliability and validity of study, and finally presentation of research findings. We also refer to it as primary research, to be differentiated from secondary research that only involves the summary, collation and/or synthesis of existing research.

In LIS, practitioner research is conducted to "improve problem solving and decision making in the workplace, to make professional practitioners critical consumers of the research literature, and to better equip librarians to provide optimal information services to researchers in other fields" (Powell et al., p. 50). Numerous studies have attested to the importance of research in the advancement of the profession. Evidence is ample in the literature that suggests research skills play an important role in librarians' work such as reference consultations, information literacy instruction, evaluation and management, and promotion and tenure (Bodi, 2002; Fister, 1992; Fister, 1993; Lenox, 1985; Perkins \& Helbig, 2008). Hernon and Schwartz (1995) summarized that research "can and should provide insights and guidance into how well library programs, services, and collections function, especially in making libraries more responsive service organizations" (p. 102).

To enhance practitioners' understanding and appreciation of the practical value of research and equip them with necessary knowledge/skills to interpret/conduct research to solve problems in the working world, offering formal research methods education in LIS degree programs plays a pivotal role (Stoan, 1984). In 2009, I conducted a Web-based survey study to examine how taking research methods courses affects LIS practice, hoping to generate more awareness about the value of research methods education among LIS practitioners, encourage them to apply research to enhance practice, and promote the evidencebased culture in LIS. A total of 555 LIS practitioners participated in the study, and 
among them, the majority was academic librarians (78.9\%), and the rest were distributed among public librarians (11.2\%), government librarians (4.5\%), and librarians working in various other types of libraries such as corporate libraries, law libraries, medical libraries, digital libraries, research libraries, school libraries, and library consortia (5.6\%). A little less than half of the respondents $(42.8 \%)$ indicated that they were in management positions. Reference and information services, information literacy instruction, and development/management of collections and resources were the top three areas of job responsibility shared by most respondents.

The survey first inquired about their research involvement at work. The majority of the respondents $(84.7 \%)$ reported various types of research activities. The two most popular research activities are reading research articles and applying the findings to improve work, and examining research articles when helping patrons in reference consultations. When asked about how taking the research methods course has helped their work, four-fifth of the responses were affirmative about the course's helpfulness. Respondents noted that the course has positively influenced their work in the following six areas:

- It helps respondents better understand LIS research literature, critically evaluate published research findings, and properly apply them at work. Exemplar quotes from the respondents:

"I am able to analyse[analyze] the data when I read articles about research projects. Some of the techniques are so faulty that I ignore the results."

"Recently, I and some colleagues have been trying to persuade our administration of the need to provide more "cutting edge" types of reference. Historically resistant, (we don't even have chat reference) I sued [used] research methodology to scan the literature for stats, trends, what other libraries are doing, etc and create a proposal."

- It helps respondents develop a better understanding of research literature in other fields, and therefore be able to properly evaluate its value to patrons' information needs and to assist patrons in their research process. Exemplar quotes from the respondents:

"As a government information librarian I assist patrons with census and statistical information and my background in research methods helps me evaluate compiled statistics and those found in research articles."

"Working in a hospital library, with the focus so heavily on research and evidence, it helps me better evaluate articles, and helps me help my patron to identify which articles are researchoriented, and help quantify the value of the research they conducted." 
- It helps respondents produce reliable and valid data to facilitate the decision making process. Exemplar quotes from the respondents:

"I was able to use the knowledge of research methods to redesign the library's customer satisfaction survey so that it would provide us with valid, reliable results."

"I conduct use studies of our print journal collections. I am aware of types of use that will skew the data and can adjust the study accordingly. "'

- It helps respondents identify problems at work and properly design/implement research studies to solve the problems. Exemplar quotes from the respondents:

"We are in the midst of producing a survey to identify user needs and wants regarding databases currently offered at our institution. Knowing something about research methods has helped in putting the survey together and will help in analyzing the responses."

"Research helps to define areas that need improvement; assists in using statistical data to analyze problems and their solutions; defines different functions in the Library and helps to focus librarians on goals and objectives."

- It helps respondents write research papers for publication. Exemplar quotes from the respondents:

"When I began my MLS degree, I had no intention of doing research. Luckily our research methods class was required, because my first job out of library school is in a tenure-track position with a requirement for publishing. I have already contacted my research methods prof [professor] and thanked her profusely for what I learned in her class. Besides all the practical knowledge, she taught me to understand that if library practitioners don't do research in library science, who will?"

"I used statistics to analyze data in a study of help-seeking behavior of college students which I presented in a paper at an ACRL conference"

- It helps respondents compose grant applications. Exemplar quotes from the respondents:

"My background in research methods is especially helpful when I compose grant applications because I need to have valid and reliable research to validate my proposals."

"I am compiling information for a grant proposal which will require data to support our need and plans for the grant funds. I have been able to use my research methods class knowledge to pull 
and analyze other's data from LIS literature as well as plan out how I will conduct my own needs assessment for my library."

Respondents' opinions were elicited regarding whether the research methods course should be a required component of the MLIS degree. About three-fourths answered "yes." Respondents provided a variety of reasons to explain the necessity of including the research methods course as a mandatory part of the curriculum:

- Research is needed for working at libraries and other LIS organizations. Library operation should be evidence based, and therefore LIS professionals need to have the knowledge of valid and reliable research methods in order to interpret and conduct research to support decision making, assess and improve services, and fulfill other functional needs of the library.

- Knowledge of research methods is useful in many aspects of library work, and it is beneficial to acquire the knowledge in the MLIS program.

- Research in general is important to the profession of LIS, and everybody working in this profession should have a basic understanding of research methods, whether or not they have the need to involve research at work.

- MLIS being a graduate degree and having the word "science" in its name indicates that a basic knowledge of research should be an integral and indispensible part of the education.

- Consuming and conducting research is the pathway for LIS professionals to develop a thorough understanding of the profession, contribute to the growth of professional literature, and move the profession forward. The research methods course helps lay the foundation for this pathway.

- Many students do not have any exposure to research prior to the MLIS program, and it might be the best opportunity for them to take the research methods course during the MLIS program.

Overall, I'm excited to learn from the study that taking the research methods course is deemed helpful by most practitioners. The course offers relevant and useful knowledge that helps LIS practitioners with various aspects of their professional work, and thus constitutes an important educational experience for them. Considering the value of taking the research methods course, the majority of the practitioners, regardless of whether they work in a public or academic library and whether or not they took the research methods previously, agree that it should be made a mandatory component of the MLIS degree. Currently about $61 \%$ of LIS degree programs have this requirement, and School of Library and Information Science (SLIS) at San Jose State University (SJSU) is one of them.

At SLIS, the Research Methods course is offered in an unconventional fashion. In addition to a general-purpose course that covers the frequently used 
research methods in the field of LIS, special topics are available for students to choose based on their interest. The specializations include different types of research, such as qualitative research or action research, or different LIS domains, such as research in reference and information services or youth services. Students with different backgrounds and pursuits may choose accordingly to fulfill their needs. For example, students who intend to seek positions as children or young adults' librarians, may select the section that introduces them to the theory and methods of planning and evaluating youth services (children and young adults). Those who have an interest in working in archives may select the section that covers theory and methods of historical research and writing. In addition, the research methods course can be taken twice for two specializations to allow students to expand their repertoire of research knowledge and skills. Research methods is a complex subject and a single course can only cover a limited area. Having more than one opportunity to take the course allows students to develop a fuller and deeper understanding of research methods and their application in practitioner research in LIS. Once graduated from the MLIS program and formally engaged in professional LIS practice, practitioners may still learn about research methods via continuing education. Sometimes, roadblocks like the lack of time/financial support/administrative support may prevent them from updating their research methods knowledge. Thus, as Basker (1985) suggests, it is important that employers provide incentives and allow time for practitioners to conduct research to improve work, and encourage them to hone their research skills via continuing education.

Given the value of research to the LIS profession, on one hand, libraries and other LIS organizations should promote research activities and facilitate research methods education and training, creating a supportive environment for practitioners to continue learning about research and applying/conducting research to improve work as well as furthering the profession as a whole. On the other hand, LIS students, when preparing themselves for professional careers, need to have a grounded understanding of how research can help them with their professional practice, equip themselves with the necessary knowledge and skills from the research methods course, and better yet, have a genuine interest in research and discovery. Anthropologist and author of Their Eyes Were Watching God, Zora Neale Hurston once said, "Research is formalized curiosity. It is poking and prying with a purpose," and therefore a curious mind will always help us embrace the wonders research brings to our work and life. 


\section{References}

Basker, J. (1985). What librarians need from researchers. New Library World, 86, 147-148.

Bodi, S. (2002). How can we bridge the gap between what we teach and what they do? Some thoughts on the place of questions in the process of research. Journal of Academic Librarianship, 28, 109-114.

Fister, B. (1992). The research processes of undergraduate students. Journal of Academic Librarianship, 18, 42-43.

Fister, B. (1993). Teaching the rhetorical dimensions of research. Research Strategies, 11, 211-219.

Hernon, P. (2001). Components of the research process: Where do we need to focus attention? Journal of Academic Librarianship, 27(2), 81-89.

Jarvis, P. (1999). The Practitioner-Researcher: Developing theory from practice. San Francisco, CA: Jossey-Bass.

Lenox, M. F. (1985). The importance of using research for decision making. Top of the News, 301-302.

Perkins, G. H., \& Helbig, T. (2008). The value of LIS schools' research topics to library authors' professional work. Journal of Academic Librarianship, 34(6), 513-519.

Powell, R. R., Baker, L. M., \& Mika, J. J. (2002). Library and information science practitioners and research. Library and Information Science Research, 24, 49-72.

Stoan, S. K. (1984). Research and library skills: An analysis and interpretation. College \& Research Libraries, 45, 99-109. 